\title{
Resolving the Basal Divisions in the Stylommatophoran Land Snails and Slugs with Special Emphasis on the Position of the Scolodontidae
}

\author{
Ahmed J. Saadi ${ }^{1} \&$ Christopher M. Wade ${ }^{1 *}$ \\ ${ }^{1}$ School of Life Sciences, The University of Nottingham, University Park, Nottingham, NG7 2RD, UK. \\ ${ }^{*}$ Corresponding author
}

\begin{abstract}
The deep divisions at the base of the stylommatophoran land snails and slugs have proved to be controversial, with the phylogenetic position of the Scolodontidae remaining unresolved. Here we present a phylogenetic analysis of 34 stylommatophoran genera based on a combined dataset (5782 sites) of four loci with the aim of resolving the position of the Scolodontidae and their relationship to the 'achatinoid' and 'non-achatinoid' clades. We also evaluate the phylogenetic utility of different genes and gene partitions. The deep phylogenetic relationships within the Stylommatophora are now clearly resolved. The Scolodontidae are shown categorically to be the sister group to all other stylommatophoran groups with robust support and with all phylogeny reconstruction methods. The 'achatinoid' and 'nonachatinoid' clades are also strongly supported in the tree. The original LSU 1-5 fragment used extensively in studies of the Stylommatophora was found to be the most informative gene fragment and works well at resolving relationships at most levels in the Stylommatophora but does not reliably resolve the deep level relationships at the very base of the clade. The concatenated dataset of four genes employed in this study is not only informative at lower levels but also resolves the deep level relationships at the base of the Stylommatophora with robust support.
\end{abstract}

Keywords: Stylommatophora, Scolodontidae, 'achatinoid clade', 'non-achatinoid clade', ribosomal RNA, SSU, LSU, Histone 3, CO1 


\section{Introduction}

The stylommatophoran land snails and slugs are the largest group within the pulmonate gastropods, comprising approximately 30,000-35,000 species (Solem, 1984). They are the major group of terrestrial gastropods and are found in a diverse range of habitats (Mordan \& Wade, 2008). Stylommatophoran taxa are characterised morphologically by the absence of an operculum and generally by two pairs of tentacles on the head (Barker, 2001; Dayrat \& Tillier, 2002). The morphological complexities of the reproductive organs have proved to be valuable for recognizing species and genera in many stylommatophoran groups (Nordsieck, 1985; Tillier, 1989; Barker, 2001; Schileyko, 2003, 2004; Mead, 2004; Herbert \& Mitchell, 2008; Sutcharit et al., 2010). The Stylommatophora were originally divided into three distinct clades by Pilsbry (1900), the Orthurethra, the Heterurethra and the Sigmurethra, based on the anatomy of the excretory system, with a fourth clade, the Mesurethra, added by Baker (1955). Of these, only the Orthurethra are still universally recognized. Tillier (1989) proposed a threeway division of the Stylommatophora into Orthurethra, Brachynephra and Dolichonephra based on differences within their renal organ. Nordsieck (1992) produced an alternative taxonomy in which he divided the Stylommatophora into two clades, the Orthurethra and the Sigmurethra, based on the excretory system. Bouchet \& Rocroi (2005) divided the Stylommatophora into the Elasmognatha, the Orthurethra and the Sigmurethra, based on the morphological and molecular data available at the time. In the most recent taxonomy (Bouchet et al., 2017), the Stylommatophora have been divided into three suborders; the Achatinina ('achatinoid clade'), Helicina ('non-achatinoid clade') and Scolodontina.

Molecular studies have significantly enhanced our recent understanding of stylommatophoran relationships. Most of these studies have focused on the phylogenetic relationships of a particular family (Goodacre \& Wade, 2001; Holland \& Hadfield, 2004; Sutcharit et al., 2010; Herbert et al., 2015; Moussalli \& Herbert, 2016) or within a particular superfamily (Armbruster et al., 2005; Wade et al., 2007; Breure et al., 2010; Köhler \& Criscione, 2015; Razkin et al., 2015; Fontanilla et al., 2017). A handful of molecular studies (Wade et al., 2001, 2006; Ramirez et al., 2012; Lin et al., 2016; Teasdale et al., 2016) have focussed on the phylogenetic relationships of the Stylommatophora as a whole.

The most comprehensive molecular studies of the Stylommatophora were performed by Wade et al. (2001, 2006), based on partial sequences from the ribosomal RNA (rRNA) genecluster. Their analyses defined two groups within the Stylommatophora, the 'achatinoid' and the 'non-achatinoid' clades. These clades are now well accepted and have been adopted in the most recent taxonomy of the Stylommatophora by Bouchet et al. (2017). 
The Scolodontidae (Baker, 1925), previously known as the Systrophiidae, has a complex taxonomic history; the placement of the family in stylommatophoran taxonomies has proven to be problematic due to the small size and relatively simple shells of snails within the family (Hausdorf, 2006). Ramírez et al. (2012) undertook a molecular phylogeny of the Scolodontidae in which they placed the Scolodontidae within the stylommatophoran phylogeny of Wade et al. (2006). Their phylogenetic analyses were inconsistent in the placement of the Scolodontidae. In their neighbor-joining analysis, the Scolodontidae fell at the very base of the Stylommatophora and outside of both the 'achatinoid' and 'nonachatinoid' clades. However, in their Bayesian analysis, the Scolodontidae fell between the 'achatinoid' and 'non-achatinoid' clades as the sister taxon to the 'non-achatinoid' clade. Bouchet et al. (2017) placed the Scolodontidae in a new suborder, Scolodontina, alongside the suborder Achatinina ('achatinoid clade') and the suborder Helicina ('non-achatinoid clade').

More recently, Teasdale et al. (2016) undertook a phylogenomic analysis of the Stylommatophora. Their study provided support for the monophyly of the Helicoidea, Limacoidea, Orthurethra and Rhytidoidea but did not address the basal divisions within the Stylommatophora as it did not include any representatives of either the 'achatinoid' clade or the Scolodontidae. Lin et al. (2016) included a single 'achatinoid' taxon, Achatina fulica, in their phylogenetic tree of the Stylommatophora based on 13 mitochondrial genes. The placement of Achatina in their tree is consistent with the Wade et al $(2001,2006)$ split of the Stylommatophora into 'achatinoid' and 'non-achatinoid' clades. They did not include the Scolodontidae.

The present study aims to resolve the basal divisions within the Stylommatophora by examining the position of the Scolodontidae and their relationship to the 'achatinoid' and 'non-achatinoid' clades. Phylogenetic analyses are based on four molecular markers: almost the full-length large subunit (LSU) rRNA gene (also incorporating part of the 5.8S gene and the complete ITS-2 region), almost the full-length small subunit (SSU) rRNA gene, part of the histone three (H3) gene and part of the cytochrome oxidase subunit I (COI) gene. These represent a seven-fold increase in sequence data over the previous molecular phylogenetic studies of the Stylommatophora by Wade et al. (2006) and Ramírez et al. (2012). Additionally, we examine the phylogenetic utility of these genes by exploring and comparing the phylogenetic signals carried by the different genes. 


\section{Methods}

\subsection{Biological Material}

A total of 34 genera of stylommatophoran land snails and slugs belonging to 33 families were included in this study. Four genera of non-stylommatophoran pulmonates were also included. Siphonaria pectinata was used as an outgroup to root the phylogenetic trees. Details of the specimens, sampling localities and the collectors are given in Table 1.

Table 1. Details of specimens, sampling localities and collectors. Classification of samples follows Bouchet et al. (2017).

Superfamily Achatinoidea

Family Ferussaciidae

Family Subulinidae

Family Glessulidae

Family Achatinidae

Family Coeliaxidae

Family Thyrophorellidae

Superfamily Streptaxoidea

Family Streptaxidae

Suborder Helicina ['Non-Achatinoid Clade']
Infraorder Pupilloidei [Orthurethra]
Superfamily Pupilloidea
Family Cochlicopidae
Family Valloniidae
Family Chondrinidae
Family Enidae
Infraorder Clausilioidei
Superfamily Clausilioidea
Family Clausiliidae
Infraorder Orthalicoidei
Superfamily Orthalicoidea
Family Orthalicidae
Family Amphibulimidae
Infraorder Oleacinoidei
Superfamily Oleacinoidea
Family Spiraxidae
Superfamily Haplotrematoidea
Family Haplotrematidae
Infraorder Rhytidoidei
Superfamily Rhytidoidea
Family Rhytididae
Family Megalobulimidae
Family Dorcasiidae
Strophocheilidae

Ferussacia foilliculus (Gmelin, 1791)

Subulina striatella (Rang, 1831)

Glessula ceylanica (Pfeiffer, 1845)

Lissachatina fulica (Bowdich, 1822)

[= Achatina fulica $]$

Coeliaxis blandii (Pfeiffer, 1852)

Thyrophorella thomensis (Greeff, 1882)

Gonaxis quadrilateralis (Preston, 1910)

\begin{tabular}{|c|c|}
\hline $\begin{array}{l}\text { Los Alcornales, Prov } \\
\text { Spain }\end{array}$ & Cadiz,M. Seddon \\
\hline Kew Gardens (introduced) & F. Naggs \\
\hline Colombo, Sri Lanka & P. Karunaratne \\
\hline $\begin{array}{l}\text { Unknown (Zool. Soc. I } \\
\text { Colln.) }\end{array}$ & Lond.P. Pearce-Kelly \\
\hline New Bradford, South Africa & N. Smith \\
\hline $\begin{array}{l}\text { Zampala, São Thomé, } \\
\text { Africa }\end{array}$ & WestA. Gascoigne \\
\hline
\end{tabular}

Box Hill, Dorking, UK

P. Mordan \& E. Platts

Cochlicopa lubrica (Müller, 1774)

Vallonia excentrica Sterki, 1892

Chondrina clienta (Westerlund, 1883)

Buliminus labrosus (Olivier, 1804)

Albinaria xantostoma (Boettger, 1883)

Drymaeus discrepans (Sowerby, 1833)

Gaeotis nigrolineata (Shuttleworth, 1854)

Euglandina rosea (Férussac, 1821)

Haplotrema vancouverense (Lea, 1839)

Rhytida stephenensis (Powell, 1930)

Megalobulimus oblongus (Müller, 1774)

Dorcasia alexandri (Gray, 1938)
São Miguel, Azores

P. Mordan

Villach, Austria

P. Miltner

Saladin's Castle, Syria

P. Mordan

Crete

D. Thomaz
Guatemala

El Yunque, Puerto Rico

Moorea (Zool. Soc. Lond. Colln.) P. Pearce-Kelly

Eugene, Oregon, USA

D. Taylor

Manaaki Whenua, New Zealand D. Gleeson

Antigua (Zool. Soc. Lond. colln.) P. Pearce-Kelly

Windhoek, Namibia

C. Boix-Hinzen 


\begin{tabular}{|c|c|c|c|}
\hline Family Caryodidae & Caryodes dufresnii (Leach, 1815) & \multicolumn{2}{|c|}{ Mt Wellington, Hobart, Tasmania B. Smith } \\
\hline \multicolumn{4}{|c|}{ Infraorder Limacoidei ['Limacoid Clade'] } \\
\hline \multicolumn{4}{|c|}{ Superfamily Trochomorphoidea } \\
\hline Family Euconulidae & Euconulus fulvus (Müller, 1774) & New Forest, Hampshire, UK & P. Mordan \\
\hline \multicolumn{4}{|l|}{ Superfamily Helicarionoidea } \\
\hline Family Ariophantidae & Cryptozona bistrialis (Beck, 1837) & Sri Lanka & P. Karunaratne \\
\hline \multicolumn{4}{|l|}{ Superfamily Limacoidea } \\
\hline Family Vitrinidae & Vitrina pellucida (Müller, 1774) & Kirkdale, Derbyshire, UK & C. Wade \\
\hline \multicolumn{4}{|l|}{ Superfamily Gastrodontoidea } \\
\hline Family Oxychilidae & Oxychilus alliarius (Miller, 1822) & Deepdale, Derbyshire, UK & C. Wade \\
\hline \multicolumn{4}{|c|}{ Infraorder Helicoidei ['Helicoid Clade’] } \\
\hline \multicolumn{4}{|c|}{ Superfamily Helicoidea } \\
\hline Family Camaenidae & Satsuma japonica (Pfeiffer, 1847) & Osaka City, Japan & P. Callomon \\
\hline Family Hygromiidae & Trochulus striolata (Pfeiffer, 1828) & Deepdale, Derbyshire, UK & C. Wade \\
\hline Family Bradybaenidae & Bradybaena similaris (Férussac, 1821) & Sri Lanka & P. Karunaratne \\
\hline \multicolumn{4}{|l|}{$=$ Camaenidae } \\
\hline Family Helminthoglyptidae & Monadenia fidelis (Gray, 1834) & Oregon & D. Taylor \\
\hline \multicolumn{4}{|l|}{$=$ Xanthonychidae } \\
\hline \multicolumn{4}{|l|}{ Infraorder Arionoidei } \\
\hline \multicolumn{4}{|l|}{ Superfamily Arionoidea } \\
\hline Family Arionidae & Arion hortensis (Férussac, 1819) & Kirkdale, Derbyshire, UK & C. Wade \\
\hline Family Philomycidae & Meghimatium bilineatum (Benson, 1842) & Mauritius & O. Griffiths \\
\hline \multicolumn{4}{|l|}{ Taxa of uncertain Position } \\
\hline \multicolumn{4}{|l|}{ Superfamily Testacelloidea } \\
\hline Family Testacellidae & Testacella scutulum (Sowerby, 1821) & North London, UK & R. Hurst \\
\hline \multicolumn{4}{|l|}{ Superfamily Plectopyloidea } \\
\hline Family Corillidae & Corilla adamsi (Gude, 1914) & Sri Lanka & D. Raheem \\
\hline \multicolumn{4}{|l|}{ Suborder Scolodontina } \\
\hline \multicolumn{4}{|l|}{ Superfamily Scolodontoidea } \\
\hline Family Scolodontidae & Guestieria sp. (Crosse 1872) & Ecuador & Hilary Kingston \\
\hline \multicolumn{4}{|l|}{$=$ Systrophiidae } \\
\hline & Systrophia sp. (Pfeiffer 1855) & Ecuador & Hilary Kingston \\
\hline \multicolumn{4}{|l|}{ n-Stylommatophoran Pulmonates: } \\
\hline \multicolumn{4}{|l|}{ der Ellobiida } \\
\hline \multicolumn{4}{|l|}{ Superfamily Ellobioidea } \\
\hline Family Ellobiidae & Laemodonta sp. & Suralaya, W. Java & B. Dharma \\
\hline Family Carychiidae & Carychium tridentatum (Risso, 1826) & Abelheira, São Miguel, Azores & P. Mordan \\
\hline \multicolumn{4}{|l|}{ Suborder Systellomatophora } \\
\hline \multicolumn{4}{|l|}{ Superfamily Veronicelloidea } \\
\hline Family Veronicellidae & Laevicaulis alte (Férussac, 1823) & Dubai, United Arab Emirates & A. Green \\
\hline \multicolumn{4}{|l|}{ der Siphonariida } \\
\hline \multicolumn{4}{|l|}{ Superfamily Siphonarioidea } \\
\hline Family Siphonariidae & Siphonaria pectinata (Linnaeus, 1758) & Zamara Los Atunes, Spain & S. Hawkins \\
\hline
\end{tabular}

\subsection{DNA Extraction, PCR Amplification and Sequencing}

DNA was extracted from a small $\left(1-2 \mathrm{~mm}^{3}\right)$ tissue sample taken from the foot of the snail using a CTAB DNA extraction protocol (Goodacre \& Wade, 2001). Four molecular markers were PCR amplified including three nuclear markers: approximately 4000 nucleotides of the LSU rRNA gene (including part of the 5.8S gene, the complete ITS-2 region, and almost the full-length large subunit (LSU; 28S) gene), approximately 1800 nucleotides of the small 
subunit (SSU, 18S) rRNA gene, approximately 370 nucleotides of the histone 3 (H3) gene; and one mitochondrial marker: approximately 650 nucleotides of cytochrome oxidase subunit $\mathrm{I}(\mathrm{COI})$.

The LSU rRNA gene (also incorporating part of the 5.8S gene and ITS-2), was amplified in a nested PCR reaction using primers LSU-1ii and LSU-12 in the first round, with the primary PCR products then used as template for the secondary PCR to amplify six internal fragments (A, B, C, D, E, and F) (see Table 2 for details of primers). PCR amplification for the primary PCR was performed using the Qiagen Taq DNA polymerase and Q buffer system (1X buffer, 1X Q-solution, $0.3 \mathrm{mM}$ dNTP, $1.5 \mathrm{mM}$ magnesium chloride, $0.2 \mu \mathrm{M}$ each primer and $1 \mathrm{U}$ Taq in a $50 \mu \mathrm{L}$ final volume). Secondary PCR amplification was identical to the primary PCR with the exception that a lower $0.2 \mathrm{mM}$ concentration of dNTPs was used. The cycling conditions (with a Perkin Elmer cycler) of the primary PCR were as follows: $96^{\circ} \mathrm{C}$ for $2 \mathrm{~min}$, followed by 35 cycles of $94^{\circ} \mathrm{C}$ for $30 \mathrm{sec}, 50^{\circ} \mathrm{C}$ for $30 \mathrm{sec}, 72^{\circ} \mathrm{C}$ for $3 \mathrm{~min}$ and then a final extension step at $72^{\circ} \mathrm{C}$ for $5 \mathrm{~min}$. The secondary PCR cycle conditions were as follows: $96^{\circ} \mathrm{C}$ for $2 \mathrm{~min}$, followed by 35 cycles of $94^{\circ} \mathrm{C}$ for $30 \mathrm{sec}, 45^{\circ} \mathrm{C}$ for $1 \mathrm{~min}, 72^{\circ} \mathrm{C}$ for $2 \mathrm{~min}$ and then a final extension step at $72^{\circ} \mathrm{C}$ for $5 \mathrm{~min}$.

Similarly, the SSU rRNA gene was amplified in a nested PCR with primers $18 \mathrm{e}$ and $18 \mathrm{p}$ used for the first round and with the primary PCR products then used as template to amplify a single fragment with primers $1 \mathrm{~F}$ and $9 \mathrm{R}$. A series of 6 internal primers were used to sequence this fragment (see Table 2 for details of primers). Some samples proved difficult to amplify as a single fragment and in these cases the internal primers were used to amplify the SSU gene. Amplification was performed using BIOTAQ ${ }^{\mathrm{TM}}$ DNA polymerase (1X reaction buffer, 0.2 mM dNTPs, $2.5 \mathrm{mM}$ magnesium chloride, $0.2 \mu \mathrm{M}$ each primer and $1 \mathrm{U}$ Taq in a $25 \mu \mathrm{L}$ final volume). The PCR cycling conditions were as follows: $96^{\circ} \mathrm{C}$ for $2 \mathrm{~min}$, followed by 35 cycles of $94^{\circ} \mathrm{C}$ for $30 \mathrm{sec}, 50^{\circ} \mathrm{C}$ for $30 \mathrm{sec}, 72^{\circ} \mathrm{C}$ for $90 \mathrm{sec}$ and then a final extension step of at $72^{\circ} \mathrm{C}$ for $5 \mathrm{~min}$ for both primary and secondary PCR.

The $\mathrm{H} 3$ gene was amplified as a single fragment using primers $\mathrm{H} 3 \mathrm{aF}$ and $\mathrm{H} 3 \mathrm{aR}$ as default primers, though different combinations of primers were used with some samples where they did not amplify with the default primers (see Table 2 for a complete list of primers). The CO1 gene was also amplified as a single fragment using primers LCO 1490 and HCO 2198 for the majority of samples. A few samples did not amplify with these primers thus different combinations of primer were used (see Table 2 for a complete list of primers). The PCR amplification of the $\mathrm{H} 3$ and $\mathrm{CO} 1$ genes were performed using BIOTAQ ${ }^{\mathrm{TM}}$ DNA polymerase (1X reaction buffer, $0.2 \mathrm{mM}$ dNTPs, $2.5 \mathrm{mM}$ magnesium chloride, $0.2 \mu \mathrm{M}$ each primer and $1 \mathrm{U}$ Taq in a $25 \mu \mathrm{L}$ final volume). The thermal cycling conditions were as follows: $96^{\circ} \mathrm{C}$ for 2 
min, followed by 35 cycles of $94^{\circ} \mathrm{C}$ for $30 \mathrm{sec}, 50^{\circ} \mathrm{C}$ for $30 \mathrm{sec}, 72^{\circ} \mathrm{C}$ for $3 \mathrm{~min}$ and then a final extension step at $72^{\circ} \mathrm{C}$ for $5 \mathrm{~min}$.

Amplification products were purified from an agarose gel using a Qiagen gel extraction kit. Both sense and antisense strands were sequenced directly on an Applied Biosystems 3730 DNA sequencer using Big Dye terminator cycle sequencing chemistries at Macrogen Inc.

Table 2. Primers used for PCR amplification

\section{Primers}

\section{Large Subunit rRNA (LSU) Incorporating 5.8S and ITS2}

Primary LSU-1ii (sense): 5'-CTAGCTGCGAGAATTAATGTGA-3'

PCR [Labelled as Primer LSU-1 in Wade et al. (2006)] LSU-12 (anti-sense): 5'-TTCTGACTTAGAGGCGTTCAG-3'

A LSU-1ii (sense): 5'-CTAGCTGCGAGAATTAATGTGA-3' [Labelled as Primer LSU-1 in Wade et al. (2006)] LSU-3ii (anti-sense): 5'-ACTTTCCCTCACGGTACTTG-3' [Labelled as Primer LSU-3 in Wade et al. (2006)]

B LSU-2ii (sense): 5'-GGGTTGTTTGGGAATGCAGC-3' [Labelled as Primer LSU-2 in Wade et al. (2006)] LSU-5ii (anti-sense): 5'-GTTAGACTCCTTGGTCCGTG-3' [Labelled as Primer LSU-5 in Wade et al. (2006)]

$\mathrm{C}$ LSU-4ii (sense): 5'-GTCGGCATTCCACCCGACC-3' LSU-7 (anti-sense): 5'- GCAGGTGAGTTGTTACACACTC-3'

D LSU-6i (sense): 5'-GTGCCAAACGCTGACGCTCA-3' LSU-9i (anti-sense): 5'-ACCCAGTCCTCAGAGCCAATC-3'

E LSU-8ii (sense): 5'-GTGCACAGCCTCTAGTCGATA-3' LSU-11ii (anti-sense): 5'-TCCTCCTGAGCTCGCCTTAG-3'

F LSU-10i (sense): 5'-GGCCGCGATCCGTCTGAAGA-3' LSU-12i (anti-sense): 5'-GGCTTCTGACTTAGAGGCGTT-3'

\section{Small Subunit rRNA (SSU)}

18e (sense): 5'-CTGGTTGATCCTGCCAGT-3'

1F (sense): $5^{\prime}$-TAC CTG GTT GAT CCT GCC AGT AG-3' 18L(anti-sense) 5'-GAATTACCGCGGCTGCTGGCACC-3' 180 (sense) 5'-GGAATRATGGAATAGGACC-3' 18R anti-sense) 5'-GTCCCCTTCCGTCAATTYCTTTAAG-3' 18F3 (sense) 5'-CGAAGACGATCAGATACCG-3' 9R (anti-sense) 5' -GATCCTTCCGCAGGTTCACCTAC-3 18p (anti-sense): 5'-TAA TGATCCTTCCGCAGGTTCACC T-3'

Histone (H3)

H3aF (sense): 5'-ATGGCTCGTACCAAGCAGACVGC-3' H3aR (anti-sense): 5'-ATATCCTTRGGCATRATRAGTGAC-3'

Alternative $\mathrm{H} 3$ primers:

H3Fm (sense): 5'-ATGGCTCGTACCAAGCAGAC-3' H3Fm1 (sense): 5'-ATGGCTAGAACGAAGCAGAC-3' H3Rm (anti-sense): 5'-TCCTTGGGCATGATGGTGAC-3' H3Rm1 (anti-sense): 5'-CCAACTGAATATCTTTGGGCAT-3'

Cytochrome Oxidase Subunit I (CO1)

LCO 1490 (sense): 5'-GGTCAACAAATCATAAAGATATTGG-3' HCO 2198 (anti-sense): 5'-TAAACTTCAGGGTGACCAAAAAATCA-3'

\section{Reference}

Wade \& Mordan (2000); Wade et al. $(2001,2006)$

Fontanilla et al. (2017)

Wade \& Mordan (2000); Wade et al. $(2001,2006)$

Wade \& Mordan (2000); Wade et al. $(2001,2006)$

Wade \& Mordan (2000); 580 Wade et al. $(2001,2006)$

Wade \& Mordan (2000); Wade et al. $(2001,2006)$

Fontanilla et al. (2017)

Fontanilla et al. (2017)

Fontanilla et al. (2017)

Fontanilla et al. (2017)

Fontanilla et al. (2017)

Fontanilla et al. (2017)

Fontanilla et al. (2017)

Fontanilla et al. (2017)

Hillis \& Dixon (1991)

Giribet et al. (1996)

Halanych et al. (1998)

Halanych et al. (1998)

Passamaneck et al. (2004)

Passamaneck et al. (2004)

Giribet et al. (1996)

Halanych et al. (1998)

Colgan et al. (1998)

Colgan et al. (1998)

Fontanilla et al. (2017)

Fontanilla et al. (2017)

Fontanilla et al. (2017)

Fontanilla et al. (2017)

Folmer et al. (1994)

Folmer et al. (1994) $\sim 900-$

Fragment Size (bp)

4000 
Alternative CO1 Primers:

STY LCOi (sense): 5'-TCAACGAATCATAAGGATATTGG-3'

Fontanilla et al. (2017)

STY LCOii (sense): 5'-ACGAATCATAAGGATATTGGTAC-3'

Fontanilla et al. (2017)

STY_LCOiii (sense): 5'-TTTGGTATTTGATGTGGGTTAGT-3'

Fontanilla et al. (2017)

STY_HCO (anti-sense): 5'-GAATTAAAATATATACTTCTGGGTG-3'

Fontanilla et al. (2017)

\subsection{Sequence Processing and Phylogenetic Analyses}

DNA sequences were assembled using version 1.5.3 of the STADEN package (Staden et al., 2000). Subsequently, the sequences were manually aligned using version 2.2 of the Genetic Data Environment (GDE) package (Smith et al., 1994). The LSU (incorporating 5.8S and ITS-2) and SSU rRNA sequences were aligned using the secondary structure as a guide. The alignment of the $\mathrm{H} 3$ and $\mathrm{CO} 1$ genes was guided by translating the DNA sequences to amino acid sequences. Gblocks v.0.91b (Castresana, 2000) with default settings was used as a guide to select the reliably aligned sites from the alignments of all genes.

Phylogenetic trees were constructed using maximum likelihood (ML) (Felsenstein, 1981), neighbor-joining (NJ) (Saitou \& Nei, 1987) and Bayesian inference (BI) (Larget \& Simon, 1999). The general time reversible model incorporating gamma $(\mathrm{GTR}+\Gamma)($ Lanave et al.,1984; $\mathrm{Gu}$ et al., 1995) was used to correct for multiple substitutions. ML trees were constructed using the PhyML (version 3.0) package (Guindon et al., 2010) with tree searching following a heuristic procedure with 10 random start trees and best of nearest-neighbour-interchange and subtree-pruning-regrafting branch swapping. NJ analysis was performed using the PAUP* (version 4.0b10) package (Swofford, 2002). For NJ analysis, model parameters were estimated following an iteration process; for each tree the parameters were estimated and used to build the next tree until there was no further improvement of the likelihood score. Bootstrap resampling (Felsenstein, 1985) with 1000 replicates was undertaken for ML and NJ trees. BI analysis was undertaken using the MrBayes (version 3.1.2) package (Ronquist \& Huelsenbeck, 2003). Two independent runs with four chains of a Markov Chain Monte Carlo (MCMC) algorithm were used to explore the tree space. BI analysis was conducted for 5 million generations with tree sampling every 100 generations. To ensure adequate chain swapping, a range of heating parameters were tested with the optimal parameter used to construct the final trees. Only after the Bayesian MCMC searches had reached a stationary phase (indicating convergence of the chains onto the target distribution) was the run ended. A consensus tree was built using the last $75 \%$ of trees (burnin=12501). 


\subsection{Assessing the Phylogenetic Utility of Different Genes}

Three methods were used to explore the utility of each gene/ gene partition for phylogeny reconstruction: 1) Phylogenetic signal was measured using the tree length distribution skewness test (gl statistic) (Hillis \& Huelsenbeck, 1992) implemented in PAUP* using the randtrees command with 10,000 replicates. 2) Total number of variable sites was determined in PAUP*. 3) Bootstrap support for key nodes in the phylogenetic tree was measured with maximum likelihood bootstrap support evaluated for the following clades: Stylommatophora monophyly (A), principle split of the stylommatophoran tree between Scolodontidae and the remaining groups (B), 'achatinoid clade' (C), 'non-achatinoid clade' (D), Pupilloidei [=Orthurethra] (E), Limacoidei (F), Arionoidei (G), Orthalicoidei (H), Helicoidei (I) and Scolodontidae (J). Comparing phylogenetic signal based on nodal support has been used in several phylogenetic studies (Narechania et al., 2011; Botero-Castro et al., 2013; Sharma et al., 2014; López-Rubio et al., 2017).

\section{Nucleotide Sequence Accession Numbers}

Nucleotide sequences generated in this study have been given the GenBank accession numbers MN022656-MN022782. Full details of all sequence accessions are given in supplementary Table S1.

\section{Results}

Sequences of four genes: approximately 4000 nucleotides of the LSU rRNA gene (also incorporating approximately 80 nucleotides of the $5.8 \mathrm{~S}$ and the complete ITS-2), approximately 1800 nucleotides of the SSU rRNA gene, approximately 370 nucleotides of the $\mathrm{H} 3$ gene and approximately 650 nucleotides of the $\mathrm{CO} 1$ gene have been generated for 34 stylommatophoran genera and 4 non-stylommatophoran genera.

\subsection{Phylogenetic Analysis}

Phylogenetic trees for the Stylommatophora were constructed using a concatenated dataset of 5782 unambiguously aligned nucleotide sites. This dataset consists of 3290 nucleotides of the LSU (and 5.8S) gene, 1748 nucleotides of the SSU gene, 328 nucleotides of the $\mathrm{H} 3$ gene and 416 nucleotides of the 1st and 2nd codon positions of the CO1 gene. Individual trees for each gene were also constructed. The siphonariid Siphonaria pectinata was used as an outgroup to root the phylogenetic trees. The ITS-2 region of the rRNA cluster was removed completely from all analyses as it could not be aligned across all taxa due to its high variability. 
Likewise, the third codon positions of the CO1 gene were excluded from analyses due to saturation at these positions.

The Bayesian inference tree of the Stylommatophora based on the concatenated dataset is shown in Figure 1. Highly consistent topologies were observed with all phylogeny reconstruction methods used (BI, Figure 1; ML, supplementary Figure S1; NJ, supplementary Figure S2). The Stylommatophora are supported as a monophyletic group in 100\% ML, 99\% $\mathrm{NJ}$ bootstrap replicates and with a Bayesian posterior probability of 1.00 . The phylogenetic tree shows a principle division between the Scolodontidae on the one hand and all other stylommatophoran groups on the other. This division is strongly supported (93\% ML, 75\% $\mathrm{NJ}$ bootstraps and $\mathrm{PP}=1.00 \mathrm{BI}$ ) and with all phylogenetic analysis methods (supplementary Table S2). We also find an identical phylogenetic position for the Scolodontidae when all partial Scolodontidae sequences available on Genbank (from Ramirez et al., 2012) are included (supplementary Figure S3). The monophyly of the Scolodontidae is also robustly supported $(100 \% \mathrm{ML}, 98 \% \mathrm{NJ}$ bootstraps and $\mathrm{P}=1.00 \mathrm{BI})$. Among the remaining stylommatophoran groups, the 'achatinoid' and the 'non-achatinoid' clades are clearly resolved with high support (100\% ML, 92\% NJ bootstraps and PP=1.00 BI for the 'achatinoid clade' and $82 \% \mathrm{ML}, 93 \% \mathrm{NJ}$ bootstraps and $\mathrm{PP}=1.00 \mathrm{BI}$ for the 'non-achatinoid clade'). In the 'achatinoid clade' there is a basal dichotomy between the Streptaxoidea on the one hand and the Achatinoidea on the other $(92 \% \mathrm{ML}, 78 \% \mathrm{NJ}$ bootstraps and $\mathrm{PP}=1.00 \mathrm{BI})$. The internal relationships within the Achatinoidea are not clear except for the position of the Ferussaciidae which is well resolved in the tree with 92\% ML, 92\% NJ bootstraps and $\mathrm{PP}=1.00$ BI. Within the 'non-achatinoid clade' the Pupilloidei [=Orthurethra] are very well supported as a monophyletic group (92\% ML, 97\% NJ bootstraps, $\mathrm{PP}=1.00 \mathrm{BI}$ ). The Arionoidei and the Limacoidei are fully supported (100\% ML, 100\% NJ bootstraps, $\mathrm{PP}=1.00$ BI) as monophyletic groups. The Arionoidei has a sister group relationship with the Limacoidei, though support for this is equivocal (66\% ML bootstraps and $\mathrm{PP}=1.00 \mathrm{BI})$. The monophyly of the Orthalicoidei is very well supported (94\% ML, 93\% NJ bootstraps, $\mathrm{PP}=1.00 \mathrm{BI}$ ). The Helicoidei form a clear monophyletic group in the tree, fully supported with 100\% ML, 100\% NJ bootstraps and $\mathrm{PP}=1.00$ BI. The Haplotrematoidea and Oleacinoidea cluster with the Helicoidea with strong support (87\% ML, 96\% NJ bootstraps and $\mathrm{PP}=0.99 \mathrm{BI}$ and $84 \% \mathrm{ML}, 84 \% \mathrm{NJ}$ bootstraps and $\mathrm{PP}=1.00 \mathrm{BI}$ respectively). The Rhytidoidea are not clearly resolved in the tree but there is weak support (53\% ML bootstraps and $\mathrm{PP}=1.00 \mathrm{BI}$ ) for a group including the Caryodidae, Dorcasiidae and Rhytididae. Finally, the Pupilloidei, Arionoidei, Limacoidei, Plectopyloidea, Rhytidoidei, Testacelloidei and Clausiloidei seem to split from other 'non-achatinoid' taxa with moderate support (70\% ML, $60 \% \mathrm{NJ}$ bootstraps and $\mathrm{PP}=0.96 \mathrm{BI}$ ). 


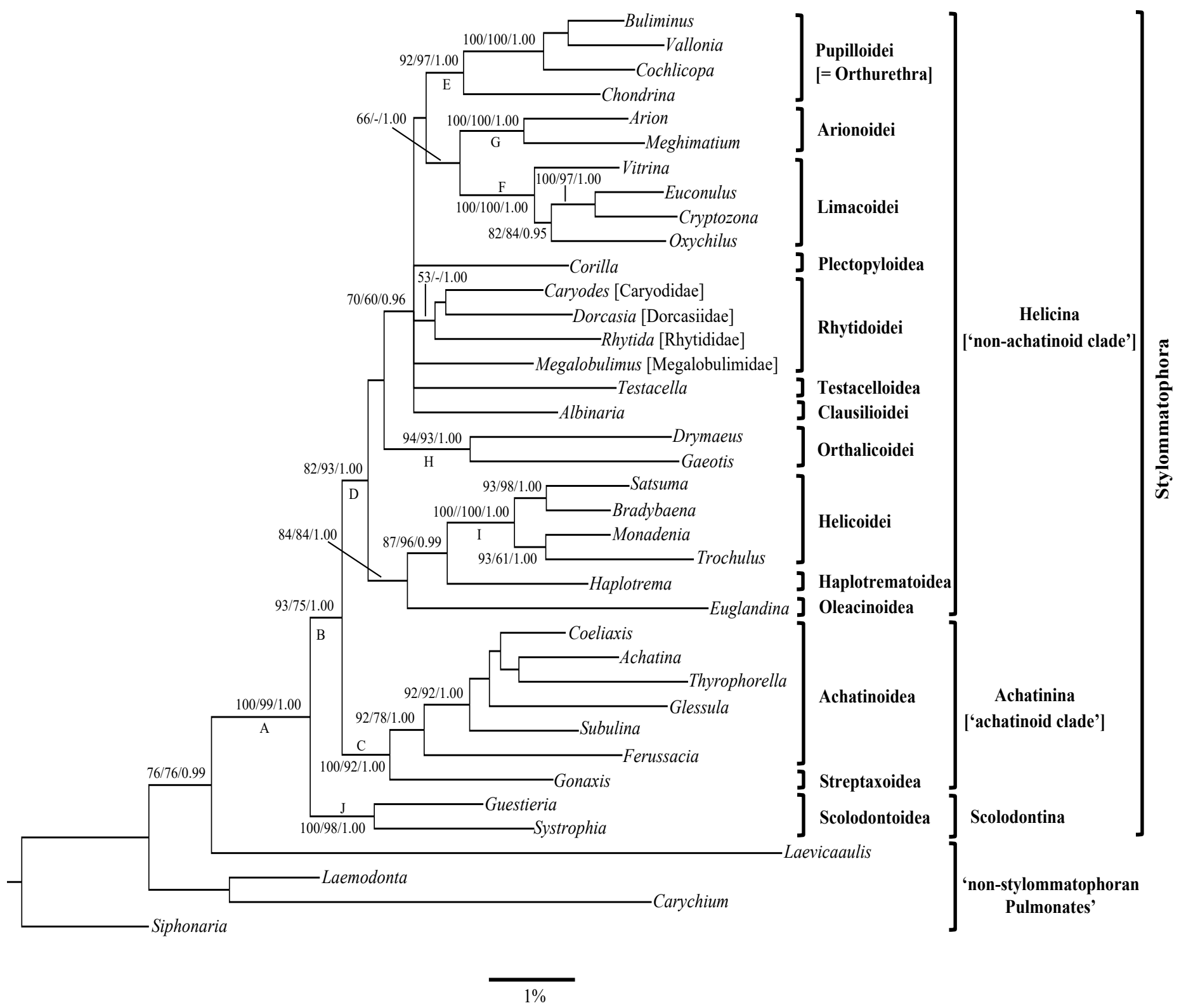

Figure 1. Bayesian phylogenetic tree of the Stylommatophora based on concatenated sequences of 5782 unambiguously aligned nucleotides from the combined dataset of the LSU (and 5.8S) gene, the SSU gene, the $\mathrm{H} 3$ gene and the 1st and 2nd codon positions of the $\mathrm{CO} 1$ gene. Values on the nodes represent bootstrap support (1000 replicates) for ML, NJ and posterior probabilities for BI (based on last $75 \%$ of trees), respectively. Bootstrap support values less than $50 \%$ and posterior probabilities less than 0.7 are not shown. The scale bar represents 1 substitutional change per 100 nucleotide positions. Nodes used to assess nodal support in analyses of the phylogenetic utility of different genes/gene partitions are shown as letters on the corresponding nodes (A-J). 


\subsection{Phylogenetic Utility of Different Genes and Partitions}

The phylogenetic utility of the different genes used in this study was evaluated to assess their usefulness for inferring stylommatophoran phylogeny. All four genes used in this study, the LSU (also incorporating the 5.8S), SSU, H3 and 1st and 2nd codon positions of CO1, as well as the concatenated dataset of all four genes were evaluated. Additionally, for the LSU gene, the utility of the full-length fragment (LSU 1-12) was compared with that of the original LSU 1-5 fragment used by Wade et al. (2001, 2006).

The values of the $g 1$ statistic for all genes and gene partitions (LSU 1-5, full-length LSU, SSU, H3, 1st and 2nd codon positions of CO1) as well as the concatenated dataset of all four genes were considerably lower than the corresponding critical values of Hillis \& Huelsenbeck (1992) indicating the presence of strong phylogenetic signal (Table 3).

Examining the number of variable sites (Table 3) revealed that within the LSU gene, the majority of the variable sites (236 sites) came from the original LSU 1-5 fragment. Expanding the sequence length of the LSU fourfold, only brought in an additional 176 sites. The SSU gene brought in an additional 140 variable sites, with 132 variable sites coming from the $\mathrm{H} 3$ gene and 122 variable sites from the $\mathrm{CO} 1$ gene (1st and 2nd codon positions).

Based on the nodal support for clades in the phylogenetic tree (Table 3), the full-length LSU gene resolved all ten stylommatophoran clades under focus. The LSU 1-5 fragment resolved nine of the ten clades, albeit with slightly lower support for some clades. Of the other genes, only two of ten clades were resolved using the SSU, three of ten clades were resolved using $\mathrm{H} 3$ and two of ten clades were resolved using the 1st and 2nd codon positions of CO1. When all four genes were combined, all ten stylommatophoran clades were recovered using the concatenated dataset, with a significant increase in bootstrap support for the deep nodes within the Stylommatophora when compared to individual genes.

Table 3. gl statistic, total number of variable sites, and bootstrap support for nodes in the stylommatophoran phylogeny for each gene/ gene partition. Nodal support values were obtained for ten clades in the stylommatophoran tree; clade letters correspond to (A) Stylommatophora monophyly, (B) principle split of the stylommatophoran tree between the Scolodontidae and all other stylommatophoran groups, (C) 'achatinoid clade', (D) 'nonachatinoid clade', (E) Pupilloidei [=Orthurethra], (F) Limacoidei, (G) Arionoidei, (H) Orthalicoidei, (I) Helicoidei and (J) Scolodontidae (clades shown on Figure 1). Where a clade is resolved the bootstrap support value is shown in the table. Clades not recovered using the gene under focus are shown as dashes (-). For the $g l$ statistic, a critical value of -0.10 at 
$\mathrm{P}=0.05$ level of significance was used for the LSU 1-5 fragment, SSU, H3 and CO1 (the 1st and the 2nd codon positions). For the full-length LSU gene a critical value of -0.08 at $\mathrm{P}=0.05$ was used. For the combined dataset of the four genes, a critical value of -0.07 at $\mathrm{P}=0.05$ was used. Critical values are dependent on the number of taxa and the total number of variable sites (critical values from Hillis and Huelsenbeck, 1992).

\begin{tabular}{|c|c|c|c|c|c|c|c|c|c|c|c|c|c|}
\hline Genes/ Gene Partitions & Sequence & & Variable & Boo & trap & uppo & For & Clad & $(\%)$ & & & & \\
\hline & Length & Statistic & Sites & A & $\mathrm{B}$ & $\mathrm{C}$ & $\mathrm{D}$ & $\mathrm{E}$ & $\mathrm{F}$ & G & $\mathrm{H}$ & I & $\mathrm{J}$ \\
\hline LSU1-5 fragment & 800 & -0.69 & 236 & 94 & - & 90 & 64 & 73 & 90 & 41 & 82 & 100 & 97 \\
\hline LSU full-length & 3290 & -0.76 & 412 & 100 & 58 & 91 & 65 & 89 & 93 & 55 & 88 & 100 & 99 \\
\hline SSU & 1748 & -0.52 & 140 & 56 & - & - & - & - & - & 36 & - & - & - \\
\hline H3 & 328 & -0.34 & 132 & - & - & - & - & - & 97 & 87 & - & - & 24 \\
\hline $\begin{array}{l}\text { 1st } \& 2 \text { nd codon positions } \\
\text { of } \mathrm{CO} 1\end{array}$ & 416 & -0.18 & 122 & - & - & - & & - & - & 51 & 37 & - & - \\
\hline $\mathrm{LSU}+\mathrm{SSU}$ & 5038 & -0.77 & 552 & 100 & 68 & 98 & 57 & 77 & 97 & 69 & 84 & 100 & 100 \\
\hline $\mathrm{LSU}+\mathrm{SSU}+\mathrm{H} 3$ & 5366 & -0.61 & 684 & 100 & 85 & 100 & 75 & 86 & 100 & 96 & 93 & 100 & 99 \\
\hline $\begin{array}{l}\mathrm{LSU}+\mathrm{SSU}+\mathrm{H} 3+1 \text { st } \& 2 \mathrm{nd} \\
\text { codon positions of } \mathrm{CO} 1\end{array}$ & 5782 & -0.65 & 806 & 100 & 93 & 100 & 82 & 92 & 100 & 100 & 94 & 100 & 100 \\
\hline
\end{tabular}

\section{Discussion}

We have examined the basal divisions in the stylommatophoran land snails and slugs and the validity of the major taxonomic groups within the clade based on a robust dataset of 5782 sites from four concatenated genes, representing a seven-fold increase in sequence data over the previous molecular phylogenetic studies of the Stylommatophora by Wade et al. (2006) and Ramírez et al. (2012).

\subsection{Phylogenetic Relationships of the Stylommatophora}

Our phylogenetic trees clearly show a basal dichotomy in the Stylommatophora between the Scolodontidae on one hand and a clade comprising all remaining stylommatophoran taxa on the other. The taxonomic position of the Scolodontidae had previously remained controversial. Tillier (1980) placed the Scolodontidae with the Endodontidae in his morphological taxonomy of the Stylommatophora. Most other morphology-based taxonomic studies placed the Scolodontidae with the Rhytidoidea (Nordsieck, 1986; Vaught, 1989; Schileyko, 2000; Bouchet \& Rocroi, 2005), while Barker (2001) placed the Scolodontidae as the sister group of a clade including the Haplotrematidae and Vitreidae. Previous molecular 
phylogenetic analyses had also failed to resolve the placement of the Scolodontidae, with Ramirez et al. (2012) showing a discrepancy in the position of the Scolodontidae according to the phylogeny reconstruction method used. Our molecular analyses now put this matter beyond doubt with the Scolodontidae falling as the sister group to all other stylommatophoran groups at the base of the stylommatophoran clade with all tree construction methods.

Our phylogenetic analyses are consistent with the previous 'achatinoid' and 'non-achatinoid' clades established by Wade et al. (2001, 2006). These groups remain stable in the current analyses, though with a significant increase in the bootstrap support for the 'non-achatinoid' clade. In earlier morphological studies, the 'achatinoid' and the 'non-achatinoid' clades were not predicted (Schileyko, 1978; Nordsieck, 1986; Tillier, 1989; Barker, 2001; Dayrat \& Tillier, 2002). Pilsbry $(1896,1900)$ recognized two main divisions within the Stylommatophora on the basis of foot morphology: the holopod and the aulacopod. The current 'achatinoid' clade includes only holopod groups, but holopod taxa also incorporate with aulacopod groups (Limacoidea, Arionodea and Endodontoidea) in the 'non-achatinoid' clade suggesting that the holopod foot is plesiomorphic. The 'achatinoid' and 'nonachatinoid' clades are well accepted and have been adopted in the most recent taxonomy of the Stylommatophora by Bouchet et al. (2017) at the same suborder level as Scolodontina, with the 'achatinoid' clade renamed as the suborder Achatinina and the 'non-achatinoid' clade renamed as the suborder Helicina. While our current phylogenetic analysis confirms the validity of these clades our findings would suggest that the 'achatinoid' and 'non-achatinoid' clades should be classified at a lower level than the Scolodontina in order to properly reflect the deep-level relationships within the Stylommatophora.

Within the 'achatinoid clade', the principle dichotomy between the Streptaxidae and Achatinoidea is well resolved with high bootstrap support. This finding agrees well with the previous molecular studies (Wade et al., 2001, 2006; Sutcharit et al., 2010). The internal relationships within the Achatinoidea are not examined here but have been examined in depth by Fontanilla et al. (2017). In the 'non-achatinoid clade', there is robust support for the Pupilloidei, Arionoidei, Limacoidei, Orthalicoidei and Helicoidei. The Arionoidei and the Limacoidei show a sister group relationship in the tree as previously observed (Wade et al., 2001, 2006) though support is equivocal. The Haplotrematoidea and Oleacinoidea fall as sister taxa of the Helicoidea as observed by Wade et al. (2006), though now with robust support. The Haplotrematoidea and Oleacinoidea were tentatively placed in a new infraorder named the Oleacinoidei by Bouchet et al. (2017) but the monophyly of this infraorder is not supported in the current phylogeny. The Rhytidoidea are represented by four families of which the Caryodidae, Dorcasiidae and Rhytididae form a clade that is poorly supported in BI and 
ML analyses, while in the NJ analysis the Rhytidoidea are resolved as a monophyletic group, but without significant support. The Rhytididae and all acavoid families were combined in one superfamily named Rhytidoidea by Bouchet et al. (2017) based on the molecular studies of Herbert et al. (2015) and Teasdale et al. (2016) as cited in Bouchet et al. (2017) where they showed the Rhytididae are nested in the Acavoidea. However, the monophyly of the Rhytidoidea in our phylogenetic trees is not clear.

\subsection{Phylogenetic Utility of Different Genes and Partitions}

The phylogenetic signal was examined directly in all genes/ gene partitions and in the combined dataset using the $g 1$ statistic. The results indicated the presence of significant phylogenetic signal in all genes/ gene partitions as well as in the concatenated dataset. Analysis of the number of variable sites reveals that within the LSU gene, the original LSU 15 fragment contains the majority of the variable sites. Although the LSU 1-5 fragment is only a quarter of the length of the full-length LSU gene, the LSU 1-5 fragment has more than 57\% of the total number of variable sites. The LSU 1-5 fragment has been used extensively in phylogenetic studies of the Stylommatophora (Wade \& Mordan 2000; Wade et al., 2001, 2006; Wade et al., 2007; Herbert \& Mitchell, 2008; Breure et al., 2010; Breure \& Romero, 2012; Ramírez et al., 2012; Herbert et al., 2015; Nekola \& Coles, 2015, Moussalli \& Herbert, 2016) where its utility is well established in resolving phylogenetic relationships among this group.

It has been suggested that the number of variable sites in nuclear genes positively correlates with the phylogenetic signal (Meyer et al., 2015). However, Kimball and Braun (2014) demonstrated that expanding the sequence length to approximately threefold from their previous study (Kimball \& Braun, 2008) resulted in only a 5\% increase on average in the bootstrap support for branches. Similarly, in our analyses we found only a modest increase in bootstrap support values for the majority of branches when using the full-length LSU compared to the LSU 1-5 fragment. However, only the full-length LSU gene resolved all ten stylommatophoran clades evaluated in our study, with just nine of ten clades resolved with the LSU 1-5 fragment. This indicates that while the LSU 1-5 fragment is the most informative part of the LSU gene, analysis of the full-length LSU gene is necessary to fully resolve the relationships within the Stylommatophora, particularly those at the base of the clade.

The SSU, H3 and CO1 (1st and 2nd codon positions) genes have fewer variable sites than the LSU and resolve only a handful of stylommatophoran clades (two or three of the ten clades evaluated) indicating that the phylogenetic information carried by these genes on their own is not sufficient to construct a robust phylogeny. However, when these genes are combined with 
the LSU, phylogenetic trees built using this concatenated dataset comprising all four genes shows a marked improvement in resolution. All ten stylommatophoran clades evaluated are recovered and there is a marked improvement in bootstrap support with all clades resolved in over $80 \%$ of bootstrap replicates and many clades fully supported. This clearly shows a significant improvement in the phylogenetic signal in the concatenated dataset compared with the individual genes. The phylogenetic relationships at the base of the stylommatophoran tree (the principle split of the tree and the support for the 'achatinoid' and the 'non-achatinoid' clades) were either not recovered or poorly supported with the individual genes. In the combined dataset, the relationships at the base of Stylommatophora are resolved with high support. These findings are consistent with previous studies that show that the concatenation of individual genes improves phylogenetic signal and produces more accurate trees (Baldauf et al. 2000; Gontcharov et al., 2004; Gadagkar et al., 2005; de Queiroz \& Gatesy, 2007; Botero-Castro et al., 2013) and it has been suggested that using multiple independent loci is a more effective approach to increase bootstrap support than increasing the sequence length of an individual gene (Corl \& Ellegren, 2013; Kimball \& Braun, 2014).

\section{Conclusion}

This paper presents the phylogenetic relationships of the Stylommatophora based on 5782 sites from four concatenated genes with special emphasis on the position of the Scolodontidae and their relationship to the 'achatinoid' and 'non-achatinoid' clades. The Scolodontidae are now shown categorically to be the sister group to all other stylommatophoran groups, with robust support with all phylogeny reconstruction methods. The results also provide strong support for the 'achatinoid' and 'non-achatinoid' clades. The principle division in the stylommatophoran tree between the Scolodontidae and a clade comprising both the 'achatinoid' and 'non-achatinoid' groups would suggest that the 'achatinoid' and 'nonachatinoid' clades should be classified at a lower taxonomic level than the Scolodontina in order to properly reflect the deep-level relationships within the Stylommatophora. 


\section{Acknowledgments}

We are extremely grateful to all of the collectors, listed in Table1, who have provided specimens. The authors also acknowledge the financial support of the Higher Committee for Education Development in Iraq (HCED-Iraq) for the PhD studies of Ahmed Saadi.

\section{References}

Armbruster, G.F., Böhme, M., Bernhard, D. and Schlegel, M., 2005. The H3/H4 histone gene cluster of land snails (Gastropoda: Stylommatophora): ts/tv ratio, GC3 drive and signals in Stylommatophoran phylogeny. J. Mollus. Stud. 71, 339-348.

Baker, H., 1925. Agnathomorphous aulacopoda. Nautilus. 38, 86-89

Baker, H., 1955. Heterurethrous and Aulacopod. Nautilus. 58, 109-112.

Baldauf, S.L., Roger, A.J., Wenk-Siefert, I. and Doolittle, W.F., 2000. A kingdom-level phylogeny of eukaryotes based on combined protein data. Science. 290, 972-977.

Barker, G.M., 2001. Gastropods on land: phylogeny, diversity and adaptive morphology. Biol. Terrest. Molluscs. pp. 1-146.

Botero-Castro, F., Tilak, M.K., Justy, F., Catzeflis, F., Delsuc, F. and Douzery, E.J., 2013. Next-generation sequencing and phylogenetic signal of complete mitochondrial genomes for resolving the evolutionary history of leaf-nosed bats (Phyllostomidae). Mol. Phylogenet. Evol. 69, 728-739.

Bouchet, P., Rocroi, J.-P., 2005. Classification and nomenclator of the gastropod families. Malacologia 47, 1-397.

Bouchet, P., Rocroi, J.P., Hausdorf, B., Kaim, A., Kano, Y., Nützel, A., Parkhaev, P., Schrödl, M. and Strong, E.E., 2017. Revised classification, nomenclator and typification of gastropod and monoplacophoran families. Malacologia 61, 1-526.

Breure, A.S.H., Groenenberg, D.S.J. and Schilthuizen, M., 2010. New insights in the phylogenetic relations within the Orthalicoidea (Gastropoda, Stylommatophora) based on 28S sequence data. Basteria 74, 25-31.

Breure, A.S. and Romero, P.E., 2012. Support and surprises: molecular phylogeny of the land snail superfamily Orthalicoidea using a three-locus gene analysis with a divergence time analysis and ancestral area reconstruction (Gastropoda: Stylommatophora). Archiv für Molluskenkunde: Int. J. Malacol. 141, 1-20.

Castresana, J., 2000. Selection of conserved blocks from multiple alignments for their use in phylogenetic analysis. Mol. Phylogenet. Evol.17, 540-552.

Colgan, D.J., McLauchlan, A., Wilson, G.D.F., Livingston, S.P., Edgecombe, G.D., Macaranas, J., Cassis, G. and Gray, M.R., 1998. Histone H3 and U2 snRNA DNA sequences and arthropod molecular evolution. Aust. J. Zool. 46, 419-437. 
Corl, A. and Ellegren, H., 2013. Sampling strategies for species trees: the effects on phylogenetic inference of the number of genes, number of individuals, and whether loci are mitochondrial, sex-linked, or autosomal. Mol. Phylogenet. Evol.67, 358-366.

Dayrat, B. and Tillier, S., 2002. Evolutionary relationships of euthyneuran gastropods (Mollusca): a cladistic re-evaluation of morphological characters. Zool. J. Linn. Soc. $135,403-470$.

de Queiroz, A. and Gatesy, J., 2007. The supermatrix approach to systematics. Trends Ecol. Evol. 22, 34-41.

Felsenstein, J., 1981. Evolutionary trees from DNA sequences: a maximum likelihood approach. J. Mol. Evol. 17, 368-376.

Felsenstein, J., 1985. Confidence limits on phylogenies: an approach using the bootstrap. Evolution 39, 783-791.

Folmer, O., Black, M., Hoen, W., Lutz, R. and Vrijenhoek, R., 1994. DNA primers for amplification of mitochondrial cytochrome c oxidase subunit I from diverse metozoan invertebrates. Mol. Mar. Biol. Biotechnol. 3, 294-299.

Fontanilla, I.K., Naggs, F. and Wade, C.M., 2017. Molecular phylogeny of the Achatinoidea (Mollusca: Gastropoda). Mol. Phylogenet. Evol. 114, 382-385.

Gadagkar, S.R., Rosenberg, M.S., Kumar, S., 2005. Inferring species phylogenies from multiple genes: concatenated sequence tree versus consensus gene tree. J. Exp. Zool. (Mol. Dev. Evol.) 304B, 64-74.

Giribet, G., Carranza, S., Baguñà, J., Riutort, M. \& Ribera, C.,1996. First molecular evidence for the existence of a Tardigrada + Arthropoda clade. Mol. Biol. Evol. 13, 76-84.

Gontcharov, A.A., Marin, V. and Melkonian, M. 2004. Are combined analyses better than single gene phylogenies? A case study using SSU rDNA and $r b c L$ sequence comparisons in the Zygnematophyceae (Streptophyta). Mol Biol Evol. 21, 612-624.

Goodacre, S.L. and Wade, C.M., 2001. Molecular evolutionary relationships between partulid land snails of the Pacific. Proc R Soc Lond [Biol]. 268, 1-7.

Gu, X., Fu, Y.X. and Li, W.H., 1995. Maximum likelihood estimation of the heterogeneity of substitution rate among nucleotide sites. Mol. Biol. Evol. 12, 546-557.

Guindon, S., Dufayard, J.F., Lefort, V., Anisimova, M., Hordijk, W. and Gascuel, O., 2010. New algorithms and methods to estimate maximum-likelihood phylogenies: assessing the performance of PhyML 3.0. Syst. Biol. 59, 307-321.

Halanych, K.M., Lutz, R.A., Vrijenhoek, R.C., 1998. Evolutionary origins and age of vestimentiferan tube worms. Cah. Biol. Mar. 39, 355-358.

Hausdorf, B., 2006. The systematic position of Scolodonta Döring, 1875 and Scolodontidae HB Baker, 1925 (Gastropoda: Pulmonata). Zoologischer Anzeiger-A J. Compar. Zool. 245, 161-165. 
Herbert, D.G. and Mitchell, A., 2008. Phylogenetic relationships of the enigmatic land snail genus Prestonella: the missing African element in the Gondwanan superfamily Orthalicoidea (Mollusca: Stylommatophora). Biol J Linnean Soc. 96, 203-221.

Herbert, D.G., Moussalli, A. and Griffiths, O.L., 2015. Rhytididae (Eupulmonata) in Madagascar: reality or conjecture? J. Mollus. Stud. 81, 259-268.

Hillis, D.M. and Huelsenbeck, J.P., 1992. Signal, noise, and reliability in molecular phylogenetic analyses. J. Hered. 83, 189-195.

Hillis, D.M., Dixon, M.T., 1991. Ribosomal DNA: molecular evolution and phylogenetic inference. Q. Rev. Biol. 66, 411-453.

Holland, B.S. and Hadfield, M.G., 2004. Origin and diversification of the endemic Hawaiian tree snails (Achatinellidae: Achatinellinae) based on molecular evidence. Mol. Phylogenet. Evol. 32, 588-600.

Kimball, R.T. and Braun, E.L., 2008. A multigene phylogeny of Galliformes supports a single origin of erectile ability in non - feathered facial traits. J. Avian Biol. 39, 438-445.

Kimball, R.T. and Braun, E.L., 2014. Does more sequence data improve estimates of galliform phylogeny? Analyses of a rapid radiation using a complete data matrix. PeerJ. 2, e361.

Köhler, F. and Criscione, F., 2015. A molecular phylogeny of camaenid land snails from north-western Australia unravels widespread homoplasy in morphological characters (Gastropoda, Helicoidea). Mol. Phylogenet. Evol. 83, 44-55.

Lanave, C., Preparata, G., Sacone, C. and Serio, G., 1984. A new method for calculating evolutionary substitution rates. Mol. Phylogenet. Evol. 20, 86-93.

Larget, B. and Simon, D.L., 1999. Markov chain Monte Carlo algorithms for the Bayesian analysis of phylogenetic trees. Mol. Phylogenet. Evol. 16, 750-759.

Lin, J.H., Zhou, W.C., Ding, H.L., Wang, P. and Ai, H.M., 2016. The mitochondrial genome of the land snail Cernuella virgata (Da Costa, 1778): the first complete sequence in the family Hygromiidae (Pulmonata, Stylommatophora). ZooKeys. 589, 55-69

López-Rubio, A., Suaza, J.D., Porter, C., Uribe, S., Bedoya, G. and Vélez, I.D., 2017. Phylogenetic signal at the Cytb-SertRNA-IG1-ND1 mitochondrial region in Anopheles (Kerteszia) neivai Howard, Dyar \& Knab, 1913. Biomédica 37, 143-154.

Mead, A.R., 2004. Comparative reproductive anatomy in the South African giant land snails (Gastropoda: Pulmonata: Achatinidae). Zool. Meded. 78, 417-449.

Meyer, B.S., Matschiner, M. and Salzburger, W., 2015. A tribal level phylogeny of Lake Tanganyika cichlid fishes based on a genomic multi-marker approach. Mol. Phylogenet. Evol. 83, 56-71. 
Mordan, P. and Wade, C.M., 2008. Heterobranchia II: The Pulmonata. In: Ponder, W.F., Lindberg, D.R. (Eds.), Phylogeny and Evolution of the Mollusca. University of California Press, Berkeley, USA, 409-426.

Moussalli, A. and Herbert, D.G., 2016. Deep molecular divergence and exceptional morphological stasis in dwarf cannibal snails Nata sensu lato Watson, 1934 (Rhytididae) of southern Africa. Mol. Phylogenet. Evol. 95,100-115.

Narechania, A., Baker, R.H., Sit, R., Kolokotronis, S.O., DeSalle, R. and Planet, P.J., 2011. Random addition concatenation analysis: a novel approach to the exploration of phylogenomic signal reveals strong agreement between core and shell genomic partitions in the cyanobacteria. Genome Biol. Evol. 4, 30-43.

Nekola, J.C. and Coles, B.F., 2015. Supraspecific taxonomy in the Vertiginidae (Gastropoda: Stylommatophora). J. Mollus. Stud. 82, 208-212.

Nordsieck, H. 1985. The system of the Stylommatophora (Gastropoda), with special regard to the systematic position of the Clausiliidae, I. Importance of the excretory and genital systems. Arch. Molluskenk. 116, 1-24.

Nordsieck, H., 1986. The system of the Stylommatophora (Gastropoda), with special regard to the systematic position of the Clausiliidae, II. Importance of the shell and distribution. Arch. Molluskenkd. 117, 93-116.

Nordsieck H. 1992. Phylogeny and system of the Pulmonata (Gastropoda). Archiv für Molluskenkunde. 121, 31-52.

Passamaneck, Y.J., Schander, C. \& Halanych, K.M., 2004. Investigation of molluscan phylogeny using large-subunit and small-subunit nuclear rRNA sequences. Mol. Phyl. Evol. 32, 25-38.

Pilsbry, H.A., 1896. The Aulacopoda: a primary division of the monotremate land Pulmonata. Nautilus.9, 109-111.

Pilsbry H.A., 1900. On the zoological position of Achatinella and Partula. Proceedings of the Academy of Natural Sciences, Philadelphia. 52, 561-567.

Ramírez, R., Borda, V., Romero, P., Ramirez, J., Congrains, C., Chirinos, J., Ramírez, P., Velásquez, L.E. and Mejía, K., 2012. Biodiversity and endemism of the western Amazonia land snails Megalobulimus and Systrophia. Rev. Peru. Biol. 19, 059-074.

Razkin, O., Gómez-Moliner, B.J., Prieto, C.E., Martínez-Ortí, A., Arrébola, J.R., Muñoz, B., Chueca, L.J. and Madeira, M.J., 2015. Molecular phylogeny of the western Palaearctic Helicoidea (Gastropoda, Stylommatophora). Mol. Phylogenet. Evol. 83, 99-117.

Ronquist, F., Huelsenbeck, J.P., 2003. MrBayes 3: Bayesian phylogenetic inference under mixed models. Bioinformatics 19, 1572-1574. 
Saitou, N. and Nei, M., 1987. The neighbor-joining method: a new method for reconstructing phylogenetic trees. Mol. Ecol. Resour. 4, 406-425.

Schileyko, A.A. 1978. Peculiarities of the structure of the excretory system of the Pulmonata in relation to subclass classification. Malacological Review. 11, 68-70.

Schileyko, A.A., 2000. Treatise on Recent Terrestrial Pulmonate Molluscs: Rhytididae, Chlamydephoridae, Systrophiidae, Haplotrematidae, Streptaxidae, Spiraxidae, Oleacinoidae, Testacellidae. Ruthenica,, supp. 2, Part6: 731-880.

Schileyko, A.A., 2003. Treatise on Recent Terrestrial Pulmonate Molluscs: Trigonochlamydidae, Papillodermidae, Vitrinidae, Limacidae, Bielziidae, Agriolimacidae, Boettgerillidae, Camaenidae. Testacellidae. Ruthenica, supp. 2, Part11: 1467-1626.

Schileyko, A.A., 2004. Treatise on Recent Terrestrial Pulmonate Molluscs: Bradybaenidae, Monadeniidae, Xanthonychidae, Epiphragmophoridae, Helminthoglyptidae, Elonidae, Humboldtianidae, Spincterochilidae, Cochlicellidae. Testacellidae. Ruthenica, supp. 2, Part 12: 1627-1764.

Sharma, P.P., Kaluziak, S.T., Perez-Porro, A.R., Gonzalez, V.L., Hormiga, G., Wheeler, W.C. and Giribet, G., 2014. Phylogenomic interrogation of Arachnida reveals systemic conflicts in phylogenetic signal. Mol. Phylogenet. Evol. 31, 2963-2984.

Smith, S.W., Overbeek, R., Woese, C.R., Gilbert, W., Gillevet, P.M., 1994. The genetic data environment, an expandable GUI for multiple sequence analysis. Comput. Appl. Biosci. 10, 671-675.

Solem, A., 1984. A world model of land snail diversity and abundance. World-wide Snails, Biogeographical studies on non-marine 21ollusca. Brill \& Backhuys, Leiden, pp.622.

Staden, R., Beal, K.F., Bonfield, J.K., 2000. The Staden package, 1998. Methods Mol. Biol. $132,115-130$.

Sutcharit, C., Naggs, F., Wade, C.M., Fontanilla, I. and Panha, S., 2010. The new family Diapheridae, a new species of Diaphera Albers from Thailand, and the position of the Diapheridae within a molecular phylogeny of the Streptaxoidea (Pulmonata: Stylommatophora). Zool. J. Linn. Soc. 160, 1-16.

Swofford, D.L., 2002. PAUP*. Phylogenetic analysis using parsimony (*and other methods), Version 4.0b10. Sunderland, MA: Sinauer Associates.

Teasdale, L.C., Koehler, F., Murray, K.D., O’Hara, T. and Moussalli, A., 2016. Identification and qualification of 500 nuclear, single - copy, orthologous genes for the Eupulmonata (Gastropoda) using transcriptome sequencing and exon capture. Mol. Ecol. Resour. 16, 1107-1123. 
Tillier, S., 1980. Gasteropodes terrestres et fluviatiles de Guyane Francaise. Mem. Mus. Nat. Hist. nat, Paris.118, 1-175.

Tillier, S., 1989. Comparative morphology, phylogeny and classification of land snails and slugs (Gastropoda: Pulmonata: Stylommatophora). Malacologia 30, 1-303.

Vaught, K.C., 1989. A Classification of the Living Mollusca. American Malacologists Inc, Melbourne, FL.

Wade, C.M. and Mordan, P.B., 2000. Evolution within the gastropod mollscs; using the ribosomal RNA gene-cluster as an indicator of phyolgenetic relationships. J. Mollus. Stud. 66, 565-569.

Wade, C.M., Mordan, P.B., Clarke, B., 2001. A phylogeny of the land snails (Gastropoda: Pulmonata). Proc. Roy. Soc. Lond. B Bio. 268, 413-422.

Wade, C.M., Mordan, P.B., Naggs, F., 2006. Evolutionary relationships among the pulmonate land snails and slugs (Pulmonata, Stylommatophora). Biol. J. Linnean. Soc. 87, 593610.

Wade, C.M., Hudelot, C., Davison, A., Naggs, F., Mordan, P.B., 2007. Molecular phylogeny of the helicoid land snails (Pulmonata: Stylommatophora: Helicoidea), with special emphasis on the Camaenidae. J. Mollus. Stud.73, 411-415. 